\title{
When Do Consumers Believe Puffery Claims? The Moderating Role of Brand Familiarity and Repetition
}

SANG Y. LEE

sang.lee@mail.wvu.edu

Follow this and additional works at: https://researchrepository.wvu.edu/faculty_publications

Part of the Mass Communication Commons

\section{Digital Commons Citation}

LEE, SANG Y., "When Do Consumers Believe Puffery Claims? The Moderating Role of Brand Familiarity and Repetition" (2014). Faculty Scholarship. 1170.

https://researchrepository.wvu.edu/faculty_publications/1170

This Article is brought to you for free and open access by The Research Repository @ WVU. It has been accepted for inclusion in Faculty Scholarship by an authorized administrator of The Research Repository @ WVU. For more information, please contact ian.harmon@mail.wvu.edu. 
This article was downloaded by: [West Virginia University]

On: 30 April 2014, At: 11:09

Publisher: Routledge

Informa Ltd Registered in England and Wales Registered Number: 1072954 Registered office: Mortimer House, 37-41 Mortimer Street, London W1T 3J H, UK

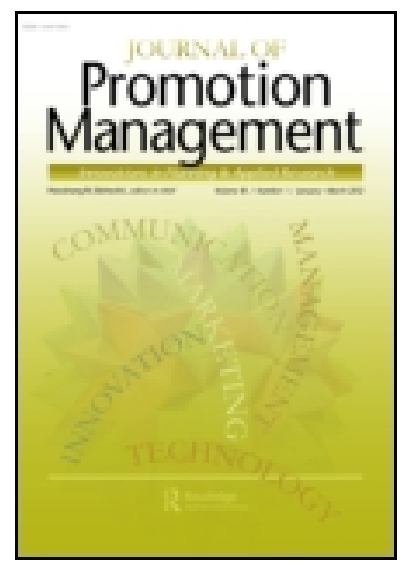

\title{
J ournal of Promotion Management
}

Publication details, including instructions for authors and subscription information:

http:// www. tandfonline.com/loi/ wjpm20

\section{When Do Consumers Believe Puffery Claims? The Moderating Role of Brand Familiarity and Repetition}

\author{
Sang Yeal Lee ${ }^{a}$ \\ ${ }^{a}$ West Virginia University, Morgantown, West Virginia, USA \\ Published online: 28 Apr 2014.
}

To cite this article: Sang Yeal Lee (2014) When Do Consumers Believe Puffery Claims? The Moderating Role of Brand Familiarity and Repetition, J ournal of Promotion Management, 20:2, 219-239, DOI: $\underline{10.1080 / 10496491.2014 .885481}$

To link to this article: http:// dx.doi.org/ 10.1080/ 10496491.2014.885481

\section{PLEASE SCROLL DOWN FOR ARTICLE}

Taylor \& Francis makes every effort to ensure the accuracy of all the information (the "Content") contained in the publications on our platform. However, Taylor \& Francis, our agents, and our licensors make no representations or warranties whatsoever as to the accuracy, completeness, or suitability for any purpose of the Content. Any opinions and views expressed in this publication are the opinions and views of the authors, and are not the views of or endorsed by Taylor \& Francis. The accuracy of the Content should not be relied upon and should be independently verified with primary sources of information. Taylor and Francis shall not be liable for any losses, actions, claims, proceedings, demands, costs, expenses, damages, and other liabilities whatsoever or howsoever caused arising directly or indirectly in connection with, in relation to or arising out of the use of the Content.

This article may be used for research, teaching, and private study purposes. Any substantial or systematic reproduction, redistribution, reselling, loan, sub-licensing, systematic supply, or distribution in any form to anyone is expressly forbidden. Terms \& Conditions of access and use can be found at http://www.tandfonline.com/page/termsand-conditions 


\title{
When Do Consumers Believe Puffery Claims? The Moderating Role of Brand Familiarity and Repetition
}

\author{
SANG YEAL LEE \\ West Virginia University, Morgantown, West Virginia, USA
}

\begin{abstract}
In the United States, exaggerated advertising claims for products and services, known as "puffery," make up a considerable proportion of all claims in the marketplace. Legally, advertisers do not need to substantiate the puffery claims because it is believed that consumers would not be deceived by such exaggerated claims. This research reports two experiments that examined the moderating role of brand familiarity and repetition on puffery claims. Results indicated that while puffery generally led to weak main effects, it had significant interaction effects with brand familiarity (Study 1) and claim repetition (Study 2) on the dependent variables.
\end{abstract}

KEYWORD puffery, puff, advertising regulation, repetition, brand familiarity

American law and regulatory agencies have traditionally recognized the rights of sellers to praise their product with commending words if those words were considered harmless to consumers. One such example is puffery expressions frequently seen in marketing communications. Puffery is a term that denotes mere exaggerations or subjective claims about the product or service reasonably expected from a seller (Better Living, Inc., 1957). Examples of puffery are "Better Ingredients, Better Pizza" (Papa Johns), "Very Best Coffee" (Nescafe), or "America's Favorite Pasta" (Mueller's). Historically, there have been twists and turns in terms of regulation on puffery claims (see Preston, 1996 for history of regulation on puffery), but in 1983 the Federal Trade Commission (FTC) officially expressed that it would not regulate puffery expressions in marketing because of the belief that puffery claims would not be seriously

Address correspondence to Dr. Sang Yeal Lee, West Virginia University, 313 Martin Hall, Morgantown, WV 26505, USA. E-mail: sang.lee@mail.wvu.edu 
perceived by consumers and would not affect purchase decisions (FTC, 1983).

The FTC's position on puffery, however, is contrary to empirical evidence. Over the years, empirical researchers have reported the positive effects of puffery claims (Rotfeld \& Rotzell, 1980; Holbrook, 1978; Kamins \& Marks, 1987; Snyder, 1989). Legal researchers have also criticized the FTC's and courts' position pertaining to puffery as "automatic immunity" (Preston, 1998), "one of the few vestiges of caveat emptor" (Leighton, 2004), and "resurgence of caveat emptor" (Goretzke, 2003). Preston (1998) in particular suggested that at least certain types of puffery be treated as deceptive information and, therefore, regulated in the marketplace.

Puffery is not only widely used in various marketing communication situations as a way to commend a product or service, it is also frequently used by companies as a defense for disputed product or service claims in common law and regulatory settings (Hoffman, 2006). Despite the importance of the topic, however, puffery has received scattered attention in the marketing communications literature.

Whereas there is a clear need for further empirical research on puffery effects in marketing communications, it is also critical to guide our research into a venue that can shed light on the legal and regulatory perspective as well as the behavioral perspective. Whereas studies examining the effects of puffery often use puffed advertising expressions, the current study focuses on two external variables that may moderate the impact of puffery, namely brand familiarity and repetition of the ad. In this study, an advertising copy affirmed by a court as puffery to empirically examine whether the court affirmed puffery expressions can influence consumers' attitudes and behavioral intentions in the contexts of brand familiarity and ad repetition.

\section{CONCEPTUAL BACKGROUND}

The rationale of the FTC's decision not to regulate puffery expressions is that puffed expressions would not significantly affect consumers' opinion and behaviors. From this perspective, one important issue in puffery research is whether consumers can differentiate factual information from puffery information. If consumers could differentiate these two types of information in their everyday marketing communication contexts, puffery claims could indeed be treated as harmless commending information that reasonable consumers would not seriously perceive. Existing research on puffery effects, however, shows somewhat mixed results on the consumer's ability to differentiate factual information from exaggerated, puffed information. In an earlier study by Rotfeld and Rotzell (1980), puffery claims were clearly perceived and believed by consumers. In their study, $80 \%$ of those who perceived puffery claims believed the puffery claims were true. The 
researchers concluded that based on the responses, subjects $(N=100)$ could not tell whether the puffery claims were untrue, despite the fact that the majority of the subjects ( 70 subjects) had college degrees or some level of college education. Holbrook also (1978) showed that consumers may not differentiate factual claims from puffery claims. He conducted an experiment comparing ads with six factual product attribute claims versus six puffery claims. Other than one attribute, he found no statistical difference between factual and puffery conditions in terms of subjects' evaluation of the strength of product attribute claims. Holbrook's study suggests that puffery claims could be as effective as factual claims, from the consumer's point of view.

Consumers' susceptibility to puffery expressions may vary depending upon the type of message presentation and the level of puffery. Kamins and Marks (1987), for example, exposed subjects to either a one-sided (i.e., positive comments on all five attributes of a product) or a two-sided (i.e., three positive comments but disclaiming two attributes) puffery claim. Their study showed that subjects were generally not deceived by high levels of puffery in a one-sided puffery claim, but they were more susceptible to deception when exposed to a two-sided claim. Their study results implied that people tend to trust two-sided messages more and therefore, if a twosided puffery claim is used, people tend to trust the claim by not discounting the puffery content in the claim. The researchers also suggested that consumers would be less likely to be deceived by extremely high puffery than by a moderate level of puffery (e.g., "good buy"). Preston (1998) also identified six different types of puffery (i.e., best, best possible, better, specially good, good and subjective qualities) based on the potential degree of deception and suggested that it can be easier to decide the falsity of information with extremely high puffery (e.g., "the most favorite ice cream in the universe!").

The believability of puffed claims can be dependent upon factors originated from consumers. Using Preston's six types of puffery, Haan and Berkey (2002) studied consumers' perceptions of the believability of puffery claims. Their survey showed that overall, consumers did not feel strongly about the believability of puffed claims. The study found little difference between the six types of puffery in terms of believability. However, consumers' believability of puffed claims was significantly influenced by external factors such as familiarity or experience with the product. Their study suggests that when the conditions are met, puffed claims can influence consumers' evaluation of the product.

Consumers also tend to believe exaggerated puffery claims in comparative advertising contexts. Snyder (1989) examined the effects of implied-superiority claims (e.g., "No toothpaste is better than Crest," or "No toothpaste makes your smile brighter than Crest"). She found that impliedsuperiority headlines were more misleading than non-comparative claims. 
Subjects interpreted implied-superiority claims to mean that the advertised brand was the best or better than others.

Gender may also play a role in understanding puffed claims. Amyx and Amyx (2011) showed that, while the effects of puffery were not as strong as expected, men tended to prefer the non-puffed message while women preferred the puffed message. They suggested that puffed expressions such as "absolutely" may serve as a probability marker and provide a sense of assurance of a promise or guaranty for women but not for men.

Although the number of empirical studies on puffery effects is limited, existing literature suggests that, unlike the FTC's position, puffery expressions in advertising can result in positive effects. The question is, therefore, under which specific conditions puffery expressions can influence consumers' attitudes and behaviors.

\section{Puffery and Brand Familiarity}

In advertising literature, research generally suggests that familiar brands have cognitive and attitudinal advantages over unfamiliar brands (Tellis, 1988). Past research shows that familiar brands can result in differential information processing and brand evaluation. For familiar brands, consumers not only can assimilate new information relevant to the familiar brand into preexisting knowledge structure more quickly, but can also process new information more efficiently with less cognitive demands (Tellis, 1988). Thus, it would require relatively fewer advertising exposures for a familiar brand to deliver a new claim and generate new attitudes toward the product, while an unfamiliar brand may need far more exposures to achieve the same level of impact. Familiar brands also tend to result in higher levels of liking toward the brand and higher purchase intention (Laroche, Kim, \& Zhou, 1996).

Research shows that the degree of brand familiarity is linked to the level of confidence toward that brand (Laroche et al., 1996). Further, credibility toward the familiar brand tends to increase the probability of inclusion in the purchase consideration set as well as actual brand choice (Erdem \& Swait, 2004). Familiar brands also tend to stand out in a cluttered advertising environment and have more persuasive power as sources of claims (Snyder, 1989). Thus, compared to an unfamiliar brand, consumers trust not only the quality of a familiar brand product but also the advertising message for that brand. As prior research suggests (Laroche et al., 1996; Erdem \& Swait; Snyder, 1989), it seems clear that positive evaluations due to familiarity with the brand can lead to higher advertising effectiveness.

In the puffery advertising context, the source of the claim can be one of the critical factors that influence the effectiveness of a puffery claim. If, for example, the brand is well- known (e.g., SONY, IBM), it is more likely that consumers would believe the exaggerated claim because 


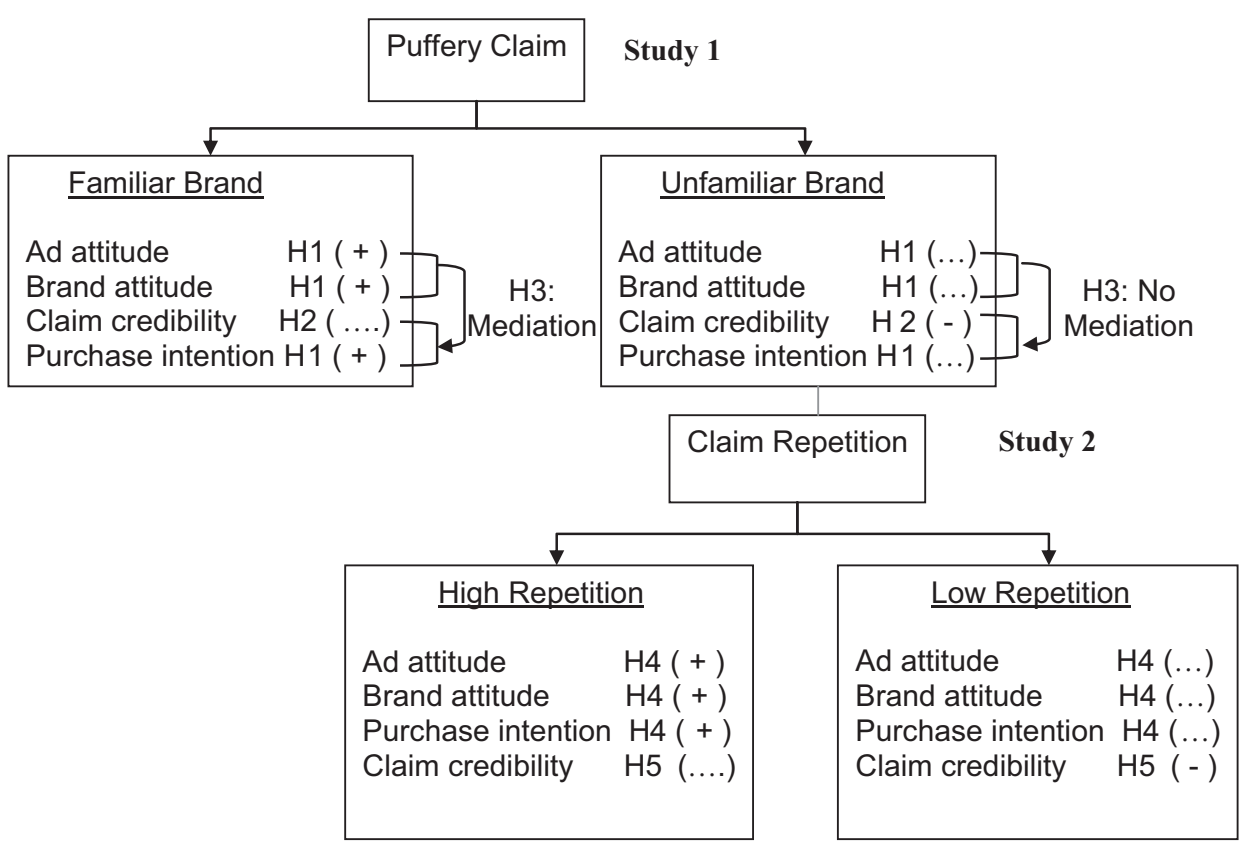

FIGURE 1 Conceptual Model.

brand familiarity is often associated with the credibility of the brand and brand-related messages. A recent study (Haan \& Berkey, 2002) also showed a high correlation between believability of the puffery claim and familiarity and experiences with the products. On the other hand, if an unknown brand is making an exaggerated puffery claim, it is more likely that consumers would discount the claim. Hence, the following hypothesis is proposed (see Figure 1 for the conceptual model):

H1: When the brand is familiar, puffery claims will result in (a) more favorable ad attitude, (b) more favorable brand attitude, and (c) higher purchase intention than no-puffery claims; in contrast, no such differences should arise when the brand is unfamiliar.

Brand familiarity can have a major impact on advertising effectiveness. Consumers' familiarity with the brand makes the brand more noticeable, attracting more attention in ads (Dahlen, 2001). Past research showed that brand familiarity has a positive impact on the attitudes toward the claims and brand (Laroche et al., 1996; Erdem \& Swait, 2004; Snyder, 1989). Consumers also tend to react confidently and are likely to show more trustworthy and credibility for familiar brand ad claims (Dalen \& Lange, 2004).

When an exaggerated puffery claim is made by a familiar brand, consumers would be less likely to discount the claim. That is, whether the claim 
is exaggerated or not, it can be perceived as credible when the brand is familiar. However, if an exaggerated claim is made by an unfamiliar brand without supporting evidence, consumers may discount the claim because they know that the claim is not coming from a credible source and, thus, likely to be false. Thus, the following hypothesis is proposed:

H2: When the brand is unfamiliar, puffery will result in lower claim credibility; in contrast; no such differences should arise when the brand is familiar.

Prior research has shown that attitudes (Laroche et al., 1996) and credibility both have a positive impact on behavior (Erdem \& Swait, 2004). One research expectation pertaining to puffery is that positive attitudes can strengthen the credibility of the claim, which in turn can lead to higher purchase intention. The key, however, can be brand familiarity. That is, depending upon the degree of brand familiarity, consumers can either perceive the claim as credible or discount the claim as not credible. In other words, when the brand in the ad is familiar, positive attitudes toward the brand and ad can bolster the credibility of the puffery claim, which can lead to higher purchase intention. The mediating role of attitudes for puffery claims, however, will dissipate when the brand is unfamiliar because the link between attitudes and credibility of the claim is weak. Thus, no such relationship is expected when the brand is unfamiliar. Accordingly, the following mediation hypothesis is advanced:

H3: For puffery claims, ad and brand attitudes will mediate the relationship between claim credibility and purchase intention when the brand is familiar, but not when the brand is unfamiliar.

\section{STUDY 1: PUFFERY AND BRAND FAMILIARITY}

\section{Stimulus Development/Pretests}

In developing the stimulus materials, the current research modeled an actual U.S. court case. There were two reasons for this decision. First, legal cases often provide detailed information about the nature of a dispute. For example, puffery cases often describe the disputed claim and the situation where the claim was made, as well as the reason why the claim was deemed to be puffery. Second and, more importantly, using an actual puffery case can increase external validity. That is, if a court declared an ad or a phrase to be puffery, it would be a good starting point to examine the effects of puffery, avoiding a potential loophole as to whether the phrase used in the research is considered puffery or not. 


\section{Selection of Product/Legal Case}

In order to select a court case for the study, legal news involving puffery disputes for five years (2002-2006) was screened using the Lexis-Nexis database. Then, 11 legal cases were reviewed with the following three guidelines in mind. First, the product in the case is, or can be, used by a significant number of study participants. Second, the disputed phrase in the case should be specifically declared by a court as a puffery claim, but should not be familiar to study participants. Third, the phrase in the case should be puffery in terms of both "standing alone" (i.e., interpreting only one component in the ad such as headline without body copy or picture) and "viewed in context" (i.e., interpreting the claim with other information in the ad such as body copy or picture). This last guideline was especially necessary to increase external validity, because even though an expression ("standing alone") is declared puffery in a court, it may not be considered puffery in a different context ("viewed in context"). As a result of the review, the American Italian Pasta Co. (2004) case met all three guidelines and was selected as an "exemplary" puffery case for the study. Accordingly, the study used pasta as a product.

\section{BRAND FAMILIARITY MANIPULATION}

Once pasta was selected as a product to be tested, the next step was to select the brands and develop stimulus materials to be used in the study. In selecting the brands, the focus was to select familiar and unfamiliar brand names that could be neutral with respect to association with quality as a pasta brand. Thus, among the many food brands including pasta brands collected from various sources, the researcher selected 10 brands that were expected to generate similar quality impressions among study participants. Then, the first pretest $(N=19)$ was conducted on these 10 brands to measure brand familiarity. As a result, $\operatorname{Kraft}(M=6.75, S D=0.62$ on a 7-point scale) was selected as a familiar brand and Zerega $(M=1.33, S D=0.88)$ was selected as an unfamiliar brand, $t(18)=16.11, p<0.01$ ).

\section{PufFERY MANipulation}

To manipulate puffery, two magazine ad versions were developed (puffery and no-puffery) based on the American Italian Pasta Co. (2004) case. The puffery version used "America's Favorite Pasta" as the headline, and took the body copy from the Mueller's pasta package without any modifications, as appeared in the American Italian Pasta Co.. In order to develop the nopuffery ad, four headlines were created and a second pretest $(N=34)$ was conducted to compare these headlines with the puffery headline "America's Favorite Pasta." As a result, "Make (brand) Your Choice of Pasta" was selected to be used as the no-puffery headline because of its similarities with the 
puffery headline, measured on a 7-point scale in terms of good/bad (puffery $M=3.00, S D=0.95$ vs. no-puffery $\mathrm{M}=3.24, S D=0.92), t(33)=-1.11, p>$ 0.05 , likable/unlikable (puffery $M=3.32, S D=0.88$ vs. no-puffery $M=3.32$, $S D=0.84), t(33)=0.00, p>0.05$, interesting/uninteresting (puffery $M=$ $2.50, S D=1.12$ vs. no-puffery $M=2.88, S D=0.98), t(33)=-1.77, p>$ 0.05 , and high quality/low quality (puffery $M=2.79, S D=0.98$ vs. nopuffery $M=3.11, S D=0.95), t(33)=-1.82, p>0.05$. For body copy in the no-puffery ad, the body copy in the puffery ad was edited. Essentially, some of the words that could be considered puffery expressions were either deleted or modified. Thus, puffery manipulation was done in terms of the presence versus non-presence of puffery. All ads also contained a picture of a pasta dish and a picture of pasta packages as well as a brand logo. Using a mock brand, the two ad versions were tested based on Preston's puffery definition (1998). A series of pair-wise $t$-test results $(N=24)$ indicated that the two ad versions were significantly different, measured on a 7-point scale in terms of "subjective" (puffery $M=3.62, S D=1.01$, no-puffery $M=2.75$, $\mathrm{SD}=.99), t(23)=2.89, p<0.01$, "superlative" (puffery $M=3.75, S D=$ .44 , no-puffery $M=3.00, S D=1.02), t(23)=3.30, p<0.01$, "exaggerated" (puffery $M=5.25, S D=2.88$, no-puffery $M=2.88, S D=1.65$ ), $t(23)=$ 4.56, $p<0.01$, "vague" (puffery $M=4.58, S D=1.14$, no-puffery $M=3.08$, $S D=1.69$ ), $t(23)=3.54, p<0.01$, and "factual" (puffery $M=3.25, S D=$ 1.33 , no-puffery $M=4.58, S D=1.41), t(23)=-2.92, p<0.01$.

\section{Procedures}

Eighty-eight students from a major university were randomly assigned to a $2 \times 2$ between-participants experimental design with two levels of puffery (puffery vs. no-puffery) and two levels of brand familiarity (familiar vs. unfamiliar). Participants were recruited from several undergraduate classes for extra credit. Fifty-seven percent were females, and the mean age was 20. Upon arriving at the lab, participants were randomly assigned to one of the four experimental conditions, and were provided with two booklets. The first booklet contained the instruction and the stimulus ad. Participants were reminded in the instruction that they were to evaluate a draft ad, and that they could spend as much time as necessary to read the ad. Participants in puffery conditions read a puffery ad with either a familiar or an unfamiliar brand and, likewise, participants in no-puffery conditions read a no-puffery ad with either a familiar or an unfamiliar brand. The second booklet was the questionnaire, containing dependent variable questions and manipulation check questions as well as some demographic questions.

\section{Dependent Measures}

The study used four dependent variables measuring participants' attitudes and intentions about the product. Ad attitude was measured with a 
TABLE 1 Summary of Descriptive Statistics for Study 1

\begin{tabular}{|c|c|c|c|c|c|c|}
\hline \multirow[b]{2}{*}{$\begin{array}{l}\text { Dependent } \\
\text { Variables }\end{array}$} & \multicolumn{3}{|c|}{ Puffery } & \multicolumn{3}{|c|}{ No puffery } \\
\hline & $\begin{array}{l}\text { Familiar } \\
(n=22)\end{array}$ & $\begin{array}{c}\text { Unfamiliar } \\
(n=24)\end{array}$ & Total & $\begin{array}{l}\text { Familiar } \\
(n=20)\end{array}$ & $\begin{array}{c}\text { Unfamiliar } \\
(n=22)\end{array}$ & Total \\
\hline Ad attitude & $5.49(0.97)$ & $\begin{array}{l}4.51 \\
(1.03)\end{array}$ & $\begin{array}{l}5.02 \\
(1.10)\end{array}$ & $4.32(1.45)$ & $4.86(0.88)$ & $4.60(1.20)$ \\
\hline Brand attitude & $5.64(0.74)$ & $\begin{array}{l}4.65 \\
(1.04)\end{array}$ & $\begin{array}{l}5.15 \\
(1.18)\end{array}$ & $4.50(1.35)$ & $5.09(0.79)$ & $4.80(1.18)$ \\
\hline Purchase intention & $5.36(1.18)$ & $\begin{array}{l}4.39 \\
(1.18)\end{array}$ & $\begin{array}{l}4.85 \\
(1.27)\end{array}$ & $4.37(1.14)$ & $4.58(1.33)$ & $4.54(1.23)$ \\
\hline Claim credibility & $5.14(0.99)$ & $\begin{array}{l}4.17 \\
(1.09)\end{array}$ & $\begin{array}{l}4.66 \\
(1.14)\end{array}$ & $4.83(1.17)$ & $4.83(1.08)$ & $4.83(1.11)$ \\
\hline
\end{tabular}

Note. Numbers in parentheses are standard deviations.

three-item, 7-point semantic differential scale, anchored by good/bad, favorable/unfavorable, and unsatisfactory/satisfactory $(\alpha=.80)$, adopted from Lafferty, Goldsmith, and Newell (2002). Brand attitude was measured by a four-item, seven-point semantic differential scale, anchored by good/bad, favorable/unfavorable, pleasant/unpleasant, and high quality/low quality ( $\alpha=.80$ ), modified from MacKenzie and Lutz (1989). Claim credibility was measured by a three-item, seven-point semantic differential scale, anchored by credible/not credible, trustworthy/not trustworthy, and believable/not believable ( $\alpha=.76)$, adopted from Beltramini (1988). Finally, purchase intention was measured with a three-item, seven point semantic differential scale, anchored by unlikely/likely, probable/improbable, and impossible/possible ( $\alpha=.80$ ), adopted from MacKenzie, Lutz, and Belch (1986).

Results

Familiarity Manipulation CHECK

Participants were asked to rate how familiar they were with the brand in the ad on a seven-point scale. Brand familiarity was significantly higher in familiar brand conditions $(M=5.95, S D=1.46)$ than in unfamiliar brand conditions $(M=1.35, S D=.10), t(72)=16.10, p<0.00$. Thus, brand familiarity manipulation was deemed successful.

\section{TeSTS OF HyPOTHESES 1 AND 2}

Descriptive statistics are presented in Table 1. A multivariate analysis of variance (MANOVA) was first run with ad attitude, brand attitude, purchase intention, and claim credibility as the dependent variables, and puffery and brand familiarity as the independent variables. Results indicated that while no significant main effects were observed, a significant interaction was observed 
TABLE 2 Multivariate and Univariate Analysis Results for Study 1

\begin{tabular}{|c|c|c|c|c|c|c|}
\hline \multirow[t]{2}{*}{ Source } & \multicolumn{2}{|c|}{ MANOVA } & \multicolumn{4}{|c|}{ ANOVA ( $F$-value) } \\
\hline & $\begin{array}{c}\text { Wilks' } \\
\lambda\end{array}$ & $F$-value & Ad attitude & Brand attitude & $\begin{array}{l}\text { Purchase } \\
\text { intention }\end{array}$ & $\begin{array}{c}\text { Claim } \\
\text { credibility }\end{array}$ \\
\hline \multicolumn{7}{|l|}{ Main effects } \\
\hline Puffery & 0.93 & 1.53 & 3.07 & 2.62 & 2.45 & 0.02 \\
\hline Familiarity & 0.94 & 1.29 & 0.82 & 0.88 & 2.19 & $4.40^{*}$ \\
\hline Interaction & & & & & & \\
\hline $\begin{array}{l}\text { Puffery } \times \\
\text { Familiarity }\end{array}$ & 0.84 & $3.90^{* *}$ & $10.56^{* *}$ & $13.72^{* *}$ & $4.40^{*}$ & $5.24^{*}$ \\
\hline
\end{tabular}

between puffery and brand familiarity, $F(2,87)=3.90, p<0.01$, Wilks's $\lambda=0.84$, partial $\eta^{2}=0.16$ (see Table 2). Then, in order to further explore the interaction as well as the main effects, separate $2 \times 2$ univariate analyses of variance (ANOVA) were run on the three dependent variables. ANOVA analyses revealed that only the main effect for brand familiarity on claim credibility was significant, $F(1,87)=4.40, p<0.05$, and all other main effects for puffery or brand familiarity were not significant. However, all interactions between puffery and brand familiarity were significant: ad attitude, $F(1,87)=$ $10.56, p<0.01$, brand attitude, $F(1,87)=13.72, p<0.01$, and purchase intention, $F(1,87)=5.24, p<0.05$.

Tests of Hypotheses 1 and 2, however, require an examination of interactions between puffery and brand familiarity on dependant variables. In testing hypothesis 1 , contrast analyses revealed that when the brand was familiar, the puffery claim led to a more favorable ad attitude (puffery $M=5.49, S D=0.97$ vs. no-puffery $M=4.32, S D=1.32), t(41)=-3.09$, $p<0.01$, higher brand attitude (puffery $M=5.64$, $S D=0.74$ vs. no-puffery $M=4.50, S D=1.35), t(41)=-3.44, p<0.01$, and higher purchase intention (puffery $M=5.36, S D=1.18$ vs no-puffery $M=4.37, S D$ $=1.14), t(41)=-2.78, p<0.01$. When the brand was unfamiliar, however, contrast analyses revealed no significant results on the dependent variables (all $p$ values $>.10$ ). Thus, Hypotheses $2 \mathrm{a}, \mathrm{b}$, and $\mathrm{c}$ are supported.

Hypothesis 2 predicted that when the brand was unfamiliar, puffery claims would result in lower claim credibility than no-puffery claims, while no such differences were expected when the brand was familiar. An ANOVA analysis revealed that while familiarity had a main effect on claim credibility, $F(1,87)=4.40, p<0.05$, puffery did not $(p$ value $>0.10)$. The interaction, however, was significant, $F(1,87)=5.24, p<0.05$. As expected, when the brand was unfamiliar, the puffery claim resulted in lower claim credibility than the no-puffery claim (puffery $M=4.17, S D=1.09$ vs no-puffery $M=$ 4.83, $S D=1.08), t(45)=2.83, p<0.05$. When the brand was familiar, 
TABLE 3 Mediation Analysis under Famous Brand Conditions (Study 1)

\begin{tabular}{lllcl}
\hline $\begin{array}{l}\text { Equation } \\
\text { number }\end{array}$ & \multicolumn{1}{c}{$\begin{array}{c}\text { Dependent } \\
\text { variable }\end{array}$} & \multicolumn{1}{c}{$\begin{array}{c}\text { Independent } \\
\text { variable(s) }\end{array}$} & $\begin{array}{c}\text { Standardized } \\
\text { regression } \\
\text { coefficient }\end{array}$ & $t$-value \\
\hline 1 & Ad attitude & Claim credibility & .55 & $4.33^{* * *}$ \\
2 & Purchase intention & Claim credibility & .41 & $2.99^{* *}$ \\
3 & Purchase intention & Ad attitude & .37 & $2.39^{*}$ \\
& & Claim credibility & .20 & 1.33 \\
4 & Brand attitude & Claim credibility & .55 & $4.40^{* * *}$ \\
5 & Purchase intention & Brand attitude & .42 & $2.75^{* *}$ \\
& & Claim credibility & .18 & 1.15 \\
\hline
\end{tabular}

${ }^{*} p<0.05 .{ }^{* *} p<0.01 .{ }^{* * *} p<0.001$.

however, puffery did not make a significant difference in claim credibility (puffery $M=5.14, S D=0.99$ vs no-puffery $M=4.83, S D=1.17$ ), $t(41$ ) $=-.91, p>0.05$, although the puffery claim was evaluated higher than the non-puffery claim. Thus, Hypothesis 2 is supported.

\section{Test OF Hypothesis 3}

A mediation analysis was performed to test Hypothesis 3, which predicted that attitudes will mediate the relationship between credibility of the puffery claim and purchase intention when the brand is familiar, but not when the brand is unfamiliar. Specifically, the mediation analysis examined whether or not the relationship between credibility of the claim and purchase intention continues to be significant when attitudes are introduced as mediators.

Following Baron and Kenny (1986), a series of regressions were run under puffery conditions (Table 3). As predicted, the mediation analysis revealed that (1) claim credibility was a significant predictor for both ad attitude $(\beta=.55, p<0.01)$ and brand attitude $(\beta=.55, p<0.01)$. Further (2), credibility of the claim was also a significant predictor for purchase intention ( $\beta=.41, p<0.01)$. When both ad attitude/brand attitude and claim credibility were regressed on purchase intention, the impact of claim credibility was no longer significant, but both ad attitude $(\beta=.37, p<0.05)$ and brand attitude $(\beta=.52, p<0.01)$ remained significant. A Sobel's test showed that attitudes (i.e., ad attitude and brand attitude) mediated the relationship between credibility of the puffery claim and purchase intention under familiar brand conditions $(z=2.04, p<.5)$. However, under unfamiliar brand conditions, claim credibility was not a significant predictor for ad attitude $(\beta=.20, p>0.05)$ or brand attitude $(\beta=.28, p>0.05)$ and accordingly, further analysis was not performed. Therefore, Hypothesis 3 was supported. 


\section{Discussion}

Results from the first experiment indicated that while both puffery and brand familiarity had rather weak main effects, they had significant interaction effects across the dependent variables. Specifically, when the brand was familiar, puffery had a significantly positive impact on ad attitude, brand attitude, and purchase intention.

These results generally confirmed the advantages of a familiar brand in the puffery advertising context. Consistent with prior research (Laroche et al., 1996), the results of Study 1 indicated that consumers tend to trust puffery claims of a familiar brand while they may have reservations trusting puffery claims of an unfamiliar brand. This tendency was clearly shown on claim credibility. Specifically, the results indicated that when the brand was unfamiliar, consumers may discount the claim, and accordingly, their evaluations for the puffery claim can be lower. When the brand is familiar, however, there were statistical differences between puffery and no-puffery ads in terms of the claim credibility. Results also indicated that ad attitude and brand attitude mediate the relationship between claim credibility and purchase intention when the brand was familiar. However, attitudes did not mediate such a relationship when the brand was unfamiliar.

Based on the results of Study 1, one question is whether the influence of puffery claims is limited to familiar brand ads. Frequency theories suggest that when people are exposed to a stimulus multiple times, they tend to get familiarized with it and form a liking toward the stimulus (Berlyne, 1970). Although there are some differences between different frequency theories, one commonality is that repetition of a novel stimulus will make individuals familiarize the content in the stimulus. From this perspective, it is possible that as the claim is repeated, consumers would evaluate the brand and ad more positively, and the disadvantages of an unfamiliar brand may disappear. Thus, Study 2 will examine whether puffery expressions by an unfamiliar brand can benefit from repetition of the claim and, accordingly, positively influence consumers' perceptions and intentions.

\section{STUDY 2: PUFFERY AND REPETITION}

Study 2 was conducted to examine the repetition effects of a puffery claim for an unfamiliar brand. Specifically, this study examined whether "standalone" puffery claims, such as "America's Favorite Pasta" without the body copy, can make a statistical difference when the puffery claim is repeated (Note that for Study 1, a headline was used with the body copy in all conditions). One main reason why only the headline was used is that a pretest showed that most participants did not read the body copy twice or three times although they read the headline and saw the graphics in the ad multiple times. 


\section{Repetition Effects of Puffery Claims}

Repetition is considered one of the fundamental determinants of advertising effectiveness and therefore has received much attention from researchers. Research consistently shows that repetition not only increases recall and recognition of the message (Cacioppo \& Petty, 1979), but also affects message recipients' attitudes toward a brand or purchase intention (Cacioppo \& Petty). The mere exposure effect (Zajonc, 1968), for example, posits that a mere increase in repetition to stimuli would increase positive affect toward the stimuli. A meta-analysis performed by Bornstein (1989) suggested that the mere exposure effect is a "robust" phenomenon in human cognition, and that preferences could be formed without conscious awareness of preference-formation. Further, there is ample research evidence that advertising repetition can encourage a consumer to form a more favorable attitude toward the brand and influence buying decisions, even when the consumer cannot recall being exposed to the advertisement. Janiszewski (1993), for example, reported that incidental exposure to an advertising message could increase consumers' liking for the ad and brand even if they failed to recognize the ad they saw.

It should be noted, however, that repetition has a limit in advertising effectiveness. Prior research shows that when the ad is repeated multiple times, consumers begin to get bored with the ad and therefore, advertising effectiveness begins to decline. This "tedium effect" is widely known and confirmed in advertising research, although researchers do not agree as to exactly at what repetition level the tedium effect occurs (Berlyne, 1970; Bornstein, 1989; Tellis, 1988).

In the puffery advertising context, repetition can increase effectiveness of a puffery claim even for an unfamiliar brand. Specifically, when repetition is low, a puffery claim of an unfamiliar brand will result in lower evaluations, as demonstrated in Study 1. However, it is expected that as repetition increases, consumers will get familiarized with the brand and brand-related information and accordingly, display higher evaluations as prior research suggests (Zajonc, 1968; Janiszewski, 1993). That is, as the message is repeated, consumers will begin to form positive evaluations about the product and brand. Research shows that an adequate level of repetition can serve as a signal of quality, suggesting that even for an unfamiliar brand, consumers infer quality from the level of advertising repetition, although excessive repetition may backfire. Conversely, if repetition is low, a puffery claim by an unfamiliar brand will not be evaluated highly, and the credibility of the message can be even lower, as demonstrated in Study 1. Hence, the following hypotheses are proposed:

H4: Puffery will interact with repetition such that a puffery claim (versus a no- puffery claim) will have a more positive impact on (a) ad attitude, 
(b) brand attitude, and (c) purchase intention under high repetition, but not under low repetition.

H5: Puffery will interact with repetition such that a puffery claim (versus a no- puffery claim) will have a more negative impact on claim credibility under low repetition, but not under high repetition.

\section{Stimulus Development}

In Study 2, the actual brand in the American Italian Pasta Co. (2004) case, Mueller's brand, was used. A preliminary test indicated that Mueller's was a relatively unknown brand to study participants. Stimulus materials were the same as in Study 1, except that there was only the headline and either a puffery claim or no-puffery claim, without the body copy.

Then, to manipulate repetition (once or three times), two additional slightly varied ad versions for each of the two puffery conditions were created, resulting in a total of six test ads (three puffery and three no-puffery ads). In varying the content of the ads, only minor cosmetic changes were made, such as changes in fonts, background color, or location of the picture. The stimulus ads needed to vary slightly because some participants in a pretest asked why they were shown exactly the same ad three times, although the directions in the booklet clearly specified that they would be shown three different ads. After varying the ads, another pretest was conducted and no participants asked any questions about the varied ads.

\section{Procedures and Measures}

Sixty-seven students from a major university were randomly assigned to a $2 \times 2$ between-participants experimental design with two levels of puffery (puffery vs. no-puffery) and two levels of repetition (once or three times). Participants were recruited from several undergraduate classes for extra credit. Sixty-seven percent were females and the mean age was 21.2. Participants in low repetition conditions saw one test ad (either puffery or no-puffery) and participants in high repetition conditions saw three varied ads (either three puffery or three no-puffery ads). After seeing the ads, participants filled out the questionnaire with the same dependent measures used in Study 1 and a covariate measure (brand familiarity: How familiar are you with the brand in the ad you just saw?).

\section{RESULTS}

The data were analyzed as a 2 (puffery or no-puffery) $\times 2$ (low or high repetition) factorial with brand familiarity as a covariate. Of particular interest 
TABLE 4 Summary of Descriptive Statistics for Study 2

\begin{tabular}{|c|c|c|c|c|c|c|}
\hline \multirow[b]{2}{*}{$\begin{array}{l}\text { Dependent } \\
\text { variables }\end{array}$} & \multicolumn{3}{|c|}{ Puffery } & \multicolumn{3}{|c|}{ No puffery } \\
\hline & $\begin{array}{l}\text { Low } \\
\text { repetition } \\
(n=15)\end{array}$ & $\begin{array}{c}\text { High } \\
\text { repetition } \\
(n=17)\end{array}$ & Total & $\begin{array}{l}\text { Low repetition } \\
\quad(n=18)\end{array}$ & $\begin{array}{l}\text { High } \\
\text { repetition } \\
(n=17)\end{array}$ & Total \\
\hline Ad attitude & 3.18 (1.03) & $4.69(1.12)$ & $\begin{array}{c}3.94 \\
(1.08)\end{array}$ & $4.04(1.05)$ & $3.86(1.19)$ & $\begin{array}{c}3.95 \\
(1.12)\end{array}$ \\
\hline Brand attitude & $4.33(0.82)$ & $4.88(0.78)$ & $\begin{array}{c}4.61 \\
(0.80)\end{array}$ & $4.57(0.68)$ & $4.34(0.68)$ & $\begin{array}{c}4.46 \\
(0.68)\end{array}$ \\
\hline $\begin{array}{l}\text { Purchase } \\
\text { intention }\end{array}$ & $3.60(1.38)$ & $4.65(0.99)$ & $\begin{array}{c}4.12 \\
(1.19)\end{array}$ & $3.54(1.62)$ & 4.39 (1.46) & $\begin{array}{c}3.97 \\
(1.54)\end{array}$ \\
\hline $\begin{array}{l}\text { Claim } \\
\text { credibility }\end{array}$ & $2.96(0.93)$ & $3.72(0.97)$ & $\begin{array}{c}3.34 \\
(0.95)\end{array}$ & $4.13(1.27)$ & $4.08(1.22)$ & $\begin{array}{c}4.10 \\
(1.25)\end{array}$ \\
\hline
\end{tabular}

Note. Numbers in parentheses are standard deviations.

in the data analysis was whether high repetition can make any difference in the participants' evaluation of the puffery claim in the ad. Treatment means and standard deviations for all dependent variables are reported in Table 4.

To assess the overall impact of the independent variables, a multivariate analysis of variance (MANCOVA) was first run with ad attitude, brand attitude, purchase intention, and claim credibility as the dependent variables, puffery, and repetition as the independent variables, and brand familiarity as a covariate (see Table 5). Results indicated significant main effects for brand familiarity, $F(1,62)=3.91, p<0.01$, Wilks's $\lambda=0.79$, partial $\eta^{2}=0.21$, and puffery, $F(1,62)=2.97, p<0.05$, Wilks's $\lambda=0.83$, partial $\eta^{2}=0.17$, but the main effect for repetition was marginally significant, $F(1,62)=2.33$, $p>0.05$, Wilks's $\lambda=0.86$, partial $\eta^{2}=0.14$. The interaction between puffery and repetition was significant, $F(1,62)=3.56, p<0.05$, Wilks's $\lambda=0.81$, partial $\eta^{2}=0.20$

TABLE 5 Multivariate and Univariate Analysis Results for Study 2

\begin{tabular}{|c|c|c|c|c|c|c|}
\hline \multirow[b]{2}{*}{ Source } & \multicolumn{2}{|c|}{ MANCOVA } & \multicolumn{4}{|c|}{ ANCOVA ( $F$-value) } \\
\hline & Wilks' $\lambda$ & $F$-value & $\begin{array}{c}\text { Ad } \\
\text { attitude }\end{array}$ & Brand attitude & $\begin{array}{l}\text { Purchase } \\
\text { intention }\end{array}$ & $\begin{array}{c}\text { Claim } \\
\text { credibility }\end{array}$ \\
\hline \multicolumn{7}{|l|}{ Covariate } \\
\hline $\begin{array}{l}\text { Brand } \\
\text { familiarity }\end{array}$ & 0.79 & $3.91^{* *}$ & 2.66 & $6.48^{*}$ & $9.43^{* *}$ & $10.32^{* *}$ \\
\hline \multicolumn{7}{|l|}{ Main effects } \\
\hline Puffery & 0.83 & 2.33 & 0.02 & 1.42 & 0.76 & $6.60^{*}$ \\
\hline repetition & 0.86 & $2.98^{*}$ & $5.45^{*}$ & 0.44 & $7.13^{* *}$ & 1.18 \\
\hline \multicolumn{7}{|l|}{ Interaction } \\
\hline $\begin{array}{l}\text { Puffery x } \\
\text { repetition }\end{array}$ & 0.81 & $3.56^{*}$ & $11.24^{* *}$ & $6.63^{*}$ & 0.52 & $4.13^{*}$ \\
\hline
\end{tabular}

${ }^{*} p<.05 .{ }^{* *} p<.01$. 
Separate $2 \times 2$ univariate analyses of variance (ANCOVA) revealed significant main effects for puffery on claim credibility, $F(1,62)=6.60, p<0.01$. The main effects for repetition were significant on ad attitude, $F(1,62)=$ 5.45, $p<0.05$, and purchase intention, $F(1,62)=7.13, p<0.01$. All other main effects for puffery or repetition were not significant. Importantly, the interaction terms were significant on ad attitude, $F(1,62)=11.24, p<0.01$, brand attitude, $F(1,62)=6.63, p<0.05$, and claim credibility, $F(1,62)=$ $4.13, p<0.05$, but not on purchase intention, $F(1,62)=0.52, p>0.05$.

Contrast analyses revealed that under high repetition, puffery led to higher ad attitude (puffery $M=4.69, S D=1.12$ vs. no-puffery $M=3.86$, $S D=1.19$ ) $, t(33)=-2.08, p<0.05$, and higher brand attitude (puffery $M$ $=4.88, S D=0.78$ vs no-puffery $M=4.34, S D=0.82), t(33)=-2.16, p$ $<0.05$. Contrast analyses, however, revealed no significant differences on purchase intention or claim credibility, although the means were in the hypothesized directions. Under low repetition, puffery led to lower ad attitude (puffery $M=3.18, S D=1.03$ vs. no-puffery $M=4.04, S D=1.05$ ), $t(32)=$ 2.36, $p<0.05$, and lower claim credibility (puffery $M=2.96, S D=0.93$ vs. no-puffery $M=4.13, S D=1.27), t(32)=3.00, p<0.05$. Contrast analyses, however, indicated no significant differences on brand attitude or purchase intention, although the means were in the hypothesized directions. Therefore, based on these analyses, Hypothesis 4 (a) and (b) were supported, while Hypothesis 4 (c) was partially supported. Finally, hypothesis 5 was supported.

\section{Discussion}

The results from Study 2 generally showed that repetition can moderate the effects of puffery claims. Similar to the results of Study 1, while puffery had weak main effects on the dependent variables, except for claim credibility, it interacted with repetition. Results showed that, under high repetition, puffery led to higher ad and brand attitudes. These results suggest a positive impact of puffery when repetition is high. As predicted, however, under high repetition, there was no statistical difference on claim credibility between puffery and non-puffery claims, which supports our prediction that consumers would get used to the puffed message as the message was repeated. In other words, participants did not display lower credibility for a puffery claim by an unfamiliar brand when they were exposed to the puffery claim multiple times.

Under low repetition, the data analyses showed somewhat mixed results. While there were no statistically significant differences between puffed and non-puffed claims on brand attitude and purchase intention, puffery resulted in a negative impact on ad attitude. These results are somewhat counterintuitive to our results in Study 1, which showed positive influence of puffery on attitudes and intention when participants were exposed to the 
ad once. One possible explanation can be the fact that while Study 1 stimulus ads included the body copy, there was no body copy in Study 2 stimulus ads. Thus, reading the body copy of the puffed claim (Study 1) may have made a difference in evaluating the puffed claim.

\section{GENERAL DISCUSSION AND CONCLUSION}

By using a court's declared puffery claim, the current research examined the impact of puffery and its combined effects with two other critical variables, brand familiarity and repetition. These variables were selected they are two important variables in advertising and were expected to moderate the impact of puffery. This research adds knowledge to our understanding of puffery effects in advertising and provides helpful insights for discussion of puffery expressions in marketing communications.

The current research showed that puffery claims under certain conditions can affect the manner in which people evaluate the information in the ad. Specifically, this research showed that a puffery claim alone may fall short of affecting consumers' attitudes or behavioral intentions, but when combined with other variables such as brand familiarity or repetition, puffery can be a powerful tool for influencing consumers' attitudes and intentions. Study 1 showed that when the brand in the puffed ad was familiar, consumers' evaluations about the ad and brand were high. That same study also showed that while consumers negatively evaluated the credibility of the puffed claim when the brand was unfamiliar, they may not have used the same level of evaluations when the brand was familiar. These results are consistent with an earlier study done by Snyder (1989) who reported that puffery headlines by a familiar brand led to higher quality ratings than puffery claims by an unfamiliar brand. In Study 2, puffery claims by an unfamiliar brand led to higher advertising effectiveness when the message was repeated multiple times. That study specifically showed that puffery claims with high repetition can make a significant difference in terms of consumers' attitudes and intentions.

The current research provides a couple of important regulatory implications. First, when making a decision on a puffery case, regulators may want to consider other variables. Looking at the disputed puffery phrase alone can provide only a narrow interpretation of the claim and, therefore, one can reach a conclusion that the disputed puffery claim would cause no harm to consumers and competition. However, there are many situations where the same variables in an advertisement can bring very different results. The current research examined only two of such variables, brand familiarity and repetition. Study 1 showed that a familiar brand can have an advantage when communicating a puffed message to consumers. The results indicate that if a familiar brand such as Sony or Mercedes is making a puffery claim, 
it will be more believable and persuasive because consumers are familiar with these brands and likely have knowledge structure or schema for these brands. Especially when the brand is favored or trusted by consumers, the puffed claim would be more likely to be accepted without any suspicion because the content is likely to be consistent with their existing knowledge. Likewise, even an unfamiliar brand's puffery claim can be believable and persuasive if the message is repeated multiple times. The results of Study 2 imply that the consumers' content-filtering mechanism may be weakened as the message is repeated. In other words, an exaggerated puffery message by an unfamiliar source can become more effective as repetition increases. From a regulation perspective, brand familiarity and number of ad repetitions in the marketplace can be the factors to consider in deciding whether a specific claim is puffery or not. This does not suggest that an unknown brand or a small budget campaign should have more privileges, but rather, puffed claims from a familiar brand with a large advertising budget may need to be more scrutinized.

Another implication of the current research is that a puffery headline without body copy can also be effective. The results of Study 2 indicated that a single headline without body copy can have an impact in the mind of the consumer when the message is repeated multiple times. Typically, ads are repeated multiple times in the real world. The results suggest that if, for example, "Better Ingredients, Better Pizza" is repeated numerous times for an extended period, consumers are more likely to believe the claim. This may be due to a possibility that, as the message is repeated multiple times, consumers filter the information less and accept the message without critical reasoning. Even though they may suspect the truthfulness of the ad content in the first time, it is less likely that they will keep suspecting the content every time they see the ad.

The current research has several limitations. First, the ads used in this study pertain to a single product in a magazine and therefore, questions of generalizability to other products in different media still remain. For example, the effects of puffery claims may differ depending on product categories, e.g., pasta vs. automobile. Second, product involvement may be a factor that can make consumers scrutinize the advertising content. A preliminary pretest showed that college students displayed low involvement toward dried pasta. Consumers' involvement with pasta versus automobiles can be radically different and, as a result, the manner in which consumers process puffery information can be different. Third, puffery comes in many different shapes and sizes, and therefore, the results of the study do not mean all puffery claims can be believed and lead to positive advertising effectiveness. Caution should be used in interpreting the results.

Future research will benefit by identifying factors that may interact with puffery. For example, product involvement may influence consumers' evaluations on puffed claims. While puffed claims with a low involvement product 
may be accepted without diagnosis of the message, those with a high involvement product may be processed with heightened message diagnosis. Likewise, different advertising appeals may affect the believability of the puffed claims. For example, puffed claims with a humor or sex appeal may be processed different from those with a rational appeal. The effectiveness of puffery claims can also differ depending upon the credibility of the model in the ad. If the puffed claim is made by a famous celebrity or a trusted individual, consumers would be more willing to accept the claim. Additionally, future study may need to explore the possibility that perceived trustworthiness of the brand could interact with claim credibility. The current study did not control perceived trustworthiness per se.

Another area that research may pay attention to is the effects of different types of puffery claims. Preston (1998), for example, identified six different types of puffery (i.e., best, best possible, better, especially good, good and subjective qualities) based on the potential degree of deception. While it is difficult to argue that all types of puffery can evoke negative or positive consumer reactions, it seems reasonable to say that, based on the results of this research, puffery claims under certain circumstances can affect consumers' information processing and intentions.

Lastly, puffery effects may depend on consumer characteristics. For example, level of education may affect the consumer's attitudes about puffed expressions. Likewise, informed consumers or those who know the product category well are likely to understand the puffed information differently.

In conclusion, this research generally showed positive effects of puffery claims. Anecdotally speaking, advertisers would not use puffery expressions if they are not effective. The results of this research showed that puffery claims can indeed be effective, affecting consumers' attitudes and intentions. The current research tested only a couple of variables that moderate the impact of puffery expressions. It may be true that many puffery expressions are just hyperbolic claims that consumers would not seriously consider as truthful, factual information. Depending upon the conditions, however, puffery expressions can affect the consumer's information processing and behaviors. From a regulatory perspective, the results of this study suggest that regulators may need to review the legal and regulatory regime pertaining to puffery expressions.

\section{REFERENCES}

American Italian Pasta Co. v. New World Pasta Co. (2004). 371 F.3d 387 (8th Cir.). Amyx, D., \& Amyx, K. (2011). Sex and puffery in advertising: An absolutely sensational and sexually provocative experiment. International Business and Management, 2, 1-10. 
Baron, R. M., \& Kenny, D. (1986). The moderator-mediator variable distinction in social psychological research: Conceptual, strategic, and statistical considerations. Journal of personality and Social Psychology, 51, 1173-1182.

Beltramini, R. (1988). Perceived believability of Warner Label Information presented in cigarette advertising. Journal of Advertising, 17(1), 26-32.

Berlyne, D. (1970). Novelty, complexity, and hedonic value. Perception and Psychophysics, 8, 279-286.

Better Living, Inc. (1957). 54 F.T.C. 648.

Bornstein, R. (1989). Exposure and affect: Overview and meta-analysis of research, 1968-1987. Psychological Bulletin, 106, 265-289.

Cacioppo, J. T., \& Petty, R. (1979). Effects of message repetition and position on cognitive response, recall, and persuasion. Journal of Personality and Social Psychology, 37, 97-109.

Dahlén, M. (2001). Banner ads through a new lens. Journal of Advertising Research, 41(4), 23-30.

Dahlén, M., \& Lange, F. (2004). To challenge or not to challenge: Ad-brand incongruency and brand familiarity. Marketing Theory \& Paractice, 12(3), 20-35.

Erdem, T., \& Swait, J. (2004). Brand credibility and its role in brand choice and consideration. Journal of Consumer Research, 31, 191-199.

Federal Trade Commission (FTC). (1983). Policy Statement on Deception, a letter from James C. Miller to John D. Dingell: Later appended to Cliffdale Associates, Inc. (1984), 103 F.T.C. 110.

Goretzke, C. (2003). The resurgence of caveat emptor: Puffery undermines the proconsumer trend in Wisconsin's misrepresentation doctrine. Wisconsin Law Review, 171-222.

Hann, P., \& Berkey, C. (2002). A study of the believability of the forms of puffery. Journal of Marketing Communications, 8, 243-256.

Hoffman, D. (2006). The best puffery article ever. Iowa Law Review, 91, 101151.

Holbrook, M. (1978). The semantic differential and attitude research. In G. F. Summers (Ed.), Attitude measurement (pp. 235-253). Chicago, IL: Rand McNally.

Janiszewski, C. (1993). Preattentive mere exposure effects. Journal of Consumer Research, 20, 376-392.

Kamins, M., \& Marks, L. (1987). Advertising puffery: The impact of using two-sided claims on product attitude and purchase intention. Journal of Advertising, 16(4), $6-15$.

Lafferty, B., Goldsmith, R., \& Newell, S. (2002). The dual credibility model: The influence of corporate and endorser credibility on attitudes and purchase Intentions. Journal of Marketing Theory and Practice, 10, 1-12.

Laroche, M., Kim, C., \& Zhou, L. (1996). Brand familiarity and confidence as determinants of purchase intention: An empirical test in a multiple brand context. Journal of Business Research, 37, 115-120.

Leighton, R. (2004). Materiality and puffing in Lanham Act false advertising cases: The proofs, presumptions, and pretexts. Trademark Rep., 94, 585633.

Mackenzie, S., \& Lutz, R. (1989). An empirical examination of attitude toward the ad in an advertising pretest context. Journal of Marketing, 53, 48-65. 
Mackenzie, S., Lutz, R., \& Belch, G. (1986). The role of attitude toward the ad as a mediator of advertising effectiveness: A test of competing explanations. Journal of Marketing Research, 23, 130-143.

Preston, I. (1994). The great American blow-up. Madison, WI: University of Wisconsin Press.

Preston, I. (1998). Puffery and other "loophole" claims: How the law's "don't ask, don't tell" policy condones fraudulent falsity in advertising. The Journal of Law and Commerce, 1, 49-114.

Rotfeld, H., \& Rotzell, K. (1980). Is advertising puffery believed? Journal of Advertising, 9(3), 16-20, 45.

Snyder, R. (1989). Misleading characteristics of implied-superiority claims. Journal of Advertising, 18(4), 54-61.

Tellis, G. (1988). Advertising exposure, loyalty, and brand purchase: A two stage model of choice. Journal of Marketing Research, 25, 134-144.

Zajonc, R. (1968). Attitudinal effects of mere exposure. Journal of Personality and Social Psychology Monographs, 9, 1-27. 